Journal of Community Based Environmental Engineering and Management, 2019, Vol. 3, No. 1: 15-24

\title{
PENENTUAN FASILITAS SANITASI BERDASARKAN PERSEPSI SANTRI DI TAHFIDZ QUR'AN MADRASAH TSANAWIYAH (MTS) ASSALAM KOTA BANDUNG
}

\author{
Deni Rusmaya*, Anni Rochaeni, Nike Purnama Dewi \\ Program Studi Teknik Lingkungan, Universitas Pasundan
}

\begin{abstract}
Abstrak
Kegiatan yang melibatkan sanitasi di pondok pesantren merupakan hal yang harus diperhatikan agar kualitas kesehatan dan lingkungan tersebut tetap terjaga dengan baik. Salah satu pondok pesantren yang memiliki santri relatif banyak di Bandung adalah Tahfidz Qur'an Madrasah Tsanawihyah (MTS) Assalam. Pemeliharaan kesehatan dan lingkungan di MTS Assalam harus disertai dengan perencanaan dengan fasilitas kesehatan yang baik. Kajian ini dilakukan untuk merencanakan fasilitas sanitasi berdasarkan persepsi santri di Pondok Pesantren Tahfidz Qur'an MTS Assalam, Kota Bandung. Metode yang digunakan adalah menyebarkan kuisioner terhadap responden, yaitu santri, berjumlah 72 orang. Hasil survey ini memperlihatkan bahwa dominasi persepsi santri (71\%) terhadap fasilitas penanganan air limbah tergolong resiko sedang, terhadap drainase paling dominan (50\%) tergolong resiko rendah, terhadap pengelolaan sampah dominan (55\%) tergolong resiko sedang. Secara keseluruhan, dominasi persepsi santri sebanyak 71\% menggolongkan fasilitas sanitasi pada resiko sedang. Dari persepsi tersebut, maka dapat disimpulkan bahwa perlu ditingkatkan kondisi sanitasi di Pondok Pesantren Tahfidz Qur'an MTS Assalam dengan merencanakan fasilitasnya dengan baik secara kuantitas dan kualitas.
\end{abstract}

Kata kunci: Kuisioner, persepsi, pondok pesantren, sanitasi

\section{Pendahuluan}

Menurut PERMENKES RI No 1 Tahun 2013 tentang pedoman penyelenggaraan dan pembinaan pos kesehatan pesantren, bahwa dalam rangka percepatan pencapaian visi masyarakat sehat, mandiri dan berkeadilan, dilakukan berbagai upaya termasuk meningkatkan peranan pondok pesantren dalam menggerakkan masyarakat untuk menumbuh kembangkan upaya kesehatan bersumber daya masyarakat. Pondok pesantren yang merupakan wadah lembaga pendidikan agama Islam berbasis masyarakat dan sangat potensial untuk

\footnotetext{
${ }^{*}$ Penulis Korespondensi:

E-mail: denirusmaya@gmail.com

Diterima pertama kali: 18 Januari 2019

Direvisi : 15 Februari 201

Disetujui untuk publikasi: 18 Februari 2019
}

meningkatkan kualitas sumber daya manusia memerlukan dukungan program kesehatan, selain dikenal sebagai wahana tempat belajar santri dan santriwati dalam mendalami ilmu agama Islam pondok pesantren selama ini juga dikenal bermasalah dari aspek sanitasi, beberapa masalah sanitasi yang sangat umum di pondok pesantren dapat kita sebut antara lain keterbatasan sarana sanitasi dan perilaku santri yang belum berprilaku hidup bersih dan sehat (Wahyudin \& Arifin, 2015).

Pondok Pesantren Madrasah Tsanawiyah Tahfidz Al Quran Assalam adalah lembaga pendidikan formal setingkat SMP yang berbasis pondok pesantren yang berfokus pada Tahfidz Al Quran (Hafal Al Quran), didirikan oleh Drs. K.H. Habib Ustman Al'Aydarus pada tahun 2013. Lokasinya terletak di Komplek Mandala 
VI No 132 RT 04 RW 11 Kelurahan Jatihandap Kecamatan Mandalajati Kota Bandung atau 1,5 KM dari Terminal Cicaheum Bandung.

Kurangnya promosi kesehatan di pesantren dapat mempengaruhi pengetahuan dan perilaku higiene perorangan pada santri, akibatnya santri berisiko terkena tinea kruris terutama santri putera, kudis, diare, ISPA, disebabkan oleh lingkungan yang kurang sehat di Pondok Pesantren serta penurunan kualitas lingkungan tersebut dapat terlihat dari keadaan area sekitar pesantren dimana ada banyak sampah-sampah yang tidak dibuang kepada tempatnya serta sampah yang tercecer di area sekitar jalan karena pesantren ini sangat dekat dengan lingkungan warga yang padat serta jalan alternatif, sehingga apabila tidak ada penanganan yang baik maka dapat mengganggu estetika dan kenyamanan (Parman, Hamdani, Rachman, \& Pratama, 2017).

Oleh karena itu, dalam kajian ini akan dilakukan direncanakan sistem sanitasi yang lebih cenderung pada sarana sanitasi yang diharapkan mampu memenuhi standar minimal kebutuhan sesuai dengan ketetapan yang ada, terdiri dari lokasi Pondok Pesantren, penyediaan air bersih, ketersediaan jamban, pengelolaan sampah, sistem pembuangan air limbah dan sistem drainase lingkungan.

\section{Metodologi}

\section{Umum}

Metode yang digunakan dalam perencanaan ini adalah metode deskriptif yang lazim digunakan dalam pengumpulan data, baik data primer maupun data sekunder yang biasanya dilaksanakan dalam bentuk teknik survey dengan wawancara dan pengamatan di lapangan.

Tahapan kajian ini adalah sebagai berikut:

1. Persiapan

2. Dokumentasi data/ pengumpulan data.

- Air bersih
- Air Buangan

- Persampahan

3. Analisa dan evaluasi data

4. Membuat sistem perencanaan sarana sanitasi dan air bersih dan Rancangan anggaran Biaya

5. Penarikan kesimpulan

\section{Sumber Data}

Dengan data primer : pengamatan di lapangan, pembagian kuisioner, wawancara. Data sekunder: keadaan umum atau gambaran wilayah studi, data ini merupakan data tentang kondisi daerah studi, jumlah santri dan aparatur pondok pesantren serta fasilitas yang ada dilokasi studi.

\section{Analisis Data}

Penilaian terhadap kondisi sarana sanitasi dan air bersih yang ada pada saat ini, dan mengidentifikasi permasalahan yang timbul pada sarana tersebut, sehingga dapat diketahui sejauh mana permasalahan yang timbul serta untuk mengetahui dan dan memastikan kebutuhan sarana sanitasi dan air bersih yang dibutuhkan oleh pondok pesantren.

\section{Lokasi Kajian}

Pondok Pesantren Madrasah Tsanawiyah Tahfidz Al Quran Assalam adalah lembaga pendidikan formal setingkat SMP yang berbasis pondok pesantren yang berfokus pada Tahfidz Al Quran (Hafal Al Quran), didirikan oleh Drs. K.H. Habib Ustman Al'Aydarus pada tahun 2013. Lokasinya terletak di Komplek Mandala VI No.132 RT. 04 RW. 11 Kelurahan Jatihandap Kecamatan Mandalajati Kota Bandung

\section{Kuisioner}

Kondisi sanitasi yang ada di Pondok Pesantren Assalam Kota Bandung dari hasil pengamatan dan survey yang dilakukan serta penyebaran kuisioner terhadap santri dan staff sarana dan prasarana di Pondok Pesantren Assalam Kota Bandung. 
Total santri putra dan putri di Pondok Pesantren Assalam dapat dilihat pada Tabel 1.

Tabel 1. Tingkatan Kelas

\begin{tabular}{cccc}
\hline Kelas & Putra & Putri & Jumlah \\
\hline 1 & 65 & 88 & 153 \\
\hline 2 & 25 & 33 & 58 \\
\hline 3 & 26 & 23 & 49 \\
\hline Total & & & 260 \\
\hline
\end{tabular}

Cara pengisian kuisioner dilakukan dengan cara wawancara langsung dengan pengelola dan para santri, kuisioner yang didapat berdasarkan perhitungan slovin (Sevilla \& al, 2007)untuk santri didapat 72 responden dan 8 responden.

Contoh Perhitungan :

$n=\frac{N}{1+N e^{2}} n=\frac{N}{1+N e^{2}}=\frac{260}{1+260 \times 0,1^{2}}$

$=72,2$ Responden $=72$ Responden

$f i=\frac{N i}{N} \quad$ ni $=$ fi $\times \mathrm{n}$

Kelas $1: 153$ santri

Putra : $\underline{65 \text { orang }}=0,25 \times 72$ orang

260 orang

$=18$ orang

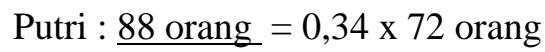

260 orang

$$
=25 \text { orang }
$$

Jadi responden untuk kelas 1 yakni 43 orang

Kelas $2: 58$ santri

Putra $: \underline{25 \text { orang }}=0,1 \times 72$ orang

$$
\begin{aligned}
& 260 \text { orang } \\
& =7 \text { orang }
\end{aligned}
$$

Putri : $\underline{33 \text { orang }}=0,13 \times 72$ orang

$$
\begin{aligned}
& 260 \text { orang } \\
& =9 \text { orang }
\end{aligned}
$$

Jadi, responden untun kelas 2 yakni 16 orang
Kelas 3 : 49 santri

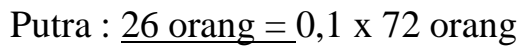

260 orang

$$
=7 \text { orang }
$$

Putri : 23 orang $=0,08 \times 72$ orang

260 orang

$=6$ orang

Jadi, responden untuk kelas 3 yakni 13 orang

Tabel 2. Jumlah Sampel Responden Santri

\begin{tabular}{ccc}
\hline Kelas & $\begin{array}{c}\text { Jenis } \\
\text { kelamin }\end{array}$ & Jumlah \\
\hline 1 & Putra & 18 orang \\
\hline 2 & Putri & 25 orang \\
\hline & Putra & 7 orang \\
\hline 3 & Putri & 9 orang \\
\hline & Putra & 7 orang \\
\hline & Putri & 6 orang \\
\hline & Jumlah & 72 orang \\
\hline
\end{tabular}

\section{Hasil dan Pembahasan}

\section{Profil Responden}

Penelitian ini dilakukan dengan cara menyebarkan kuesioner secara langsung kepada santri putri di Pondok Pesantren Assalam Kota Bandung. Karakteristik responden dalam penelitian ini terbagi dalam beberapa kategori, yaitu: jenis kelamin, kelas, lama tinggal di Pondok Pesantren Assalam Kota Bandung.

Gambar 1 memperlihatkan persentase kelas di mana responden tersebut sedang belajar. Gambar tersebut memperlihatkan bahwa pesentase tertinggi responden berasal dari kelas 1 MTS sebanyak 50\%. Sedangkan Gambar 2 memperlihatkan persentase jenis kelamin responden kelas 1. Pada diagram tersebut dijelaskan bahwa jumlah responden di kelas 1 didominasi oleh responden santri putri yakni $58 \%$ dan responden santri putra sebanyak $42 \%$. 


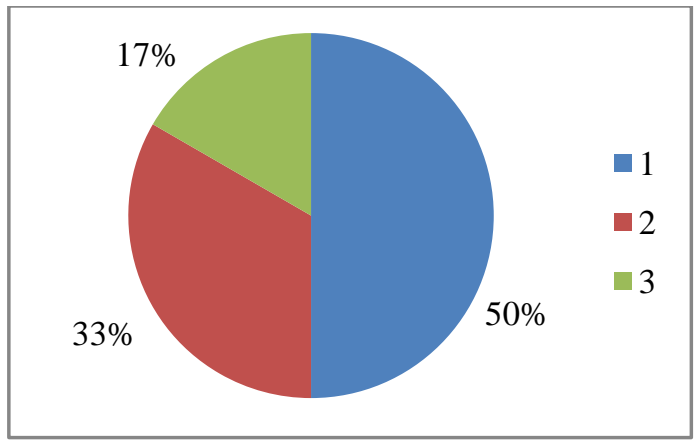

Gambar 1. Tingkat/ kelas responden

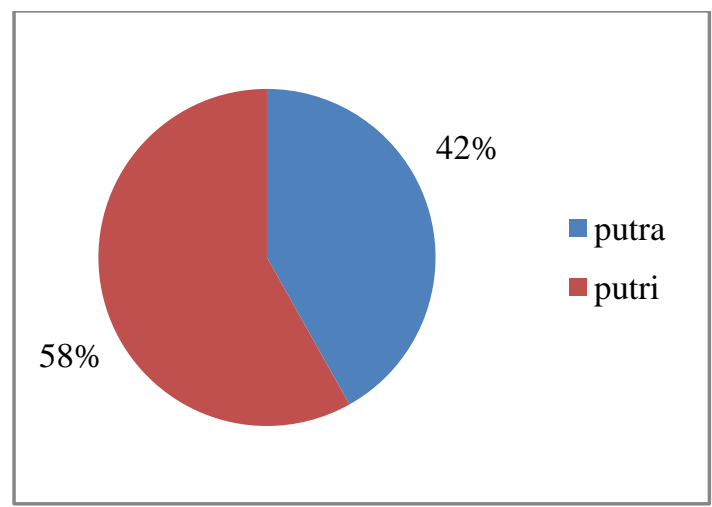

Gambar 2. Jenis kelamin responden kelas 1.

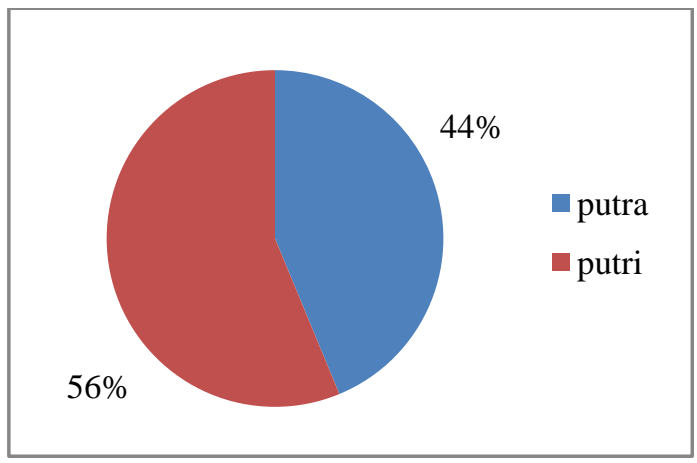

Gambar 3. Jenis kelamin responden kelas 2.

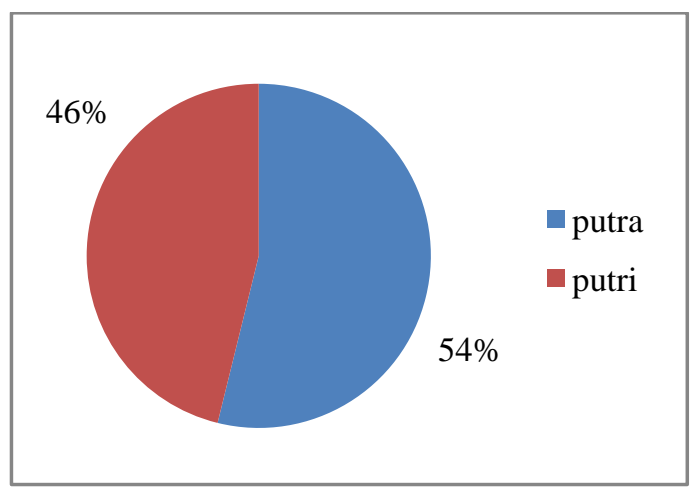

Gambar 4. Jenis kelamin responden kelas 3.
Gambar 2 memperlihatkan persentase jenis kelamin untuk reponden dari kelas 1 yang didominasi oleh santri putrid sebanyak $58 \%$. Gambar 3 dan 4 memperlihatkan persentase jenis kelamin untuk responden dari kelas 2 dan 3. Responden santri putri mendominasi jenis kelamin kelas 2 yaitu sebanyak 56\%, sedangkan responden santri putra mendominasi jenis kelamin kelas 3 yaitu sebanyak 54\%.

\section{Persepsi tentang Air Bersih}

Gambar 5 memperlihatkan jawaban responden terhadap pengetahuan mengenai sumber air bersih yang dimiliki oleh pesantren baik yang berasal dari sumur bor, atau sumber lainnya.

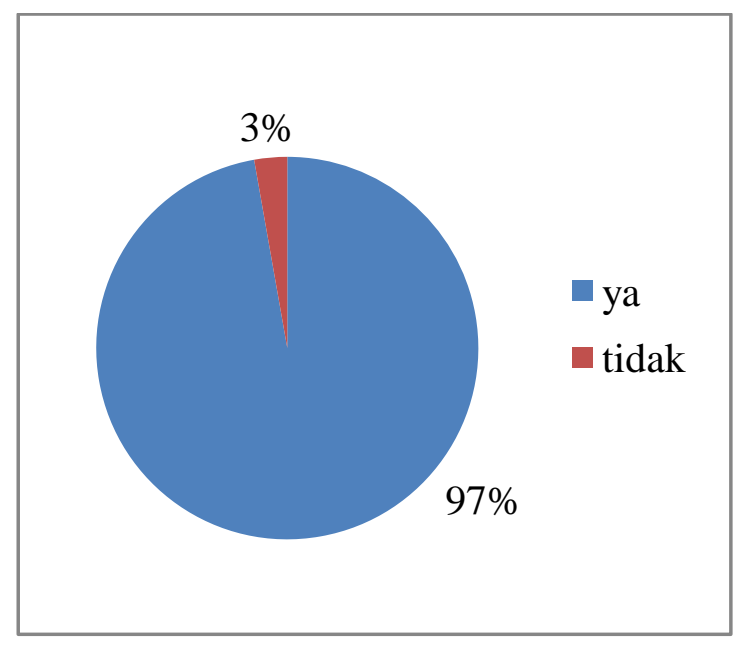

Gambar 5. Pengetahuan terhadap sumber air

Dapat dilihat pada Gambar 5 bahwa untuk responden yang menjawab "YA" sebanyak 70 responden atau sebesar $97 \%$ dikarenakan mayoritas responden telah mengetahui darimana sumber air yang mereka pergunakan setiap harinya, sedangkan untuk jawaban "TIDAK" yakni sebanyak 2 responden atau sebanyak 3\% hal tersebut bisa saja terjadi dikarenakan ketidaktahuan santri. 


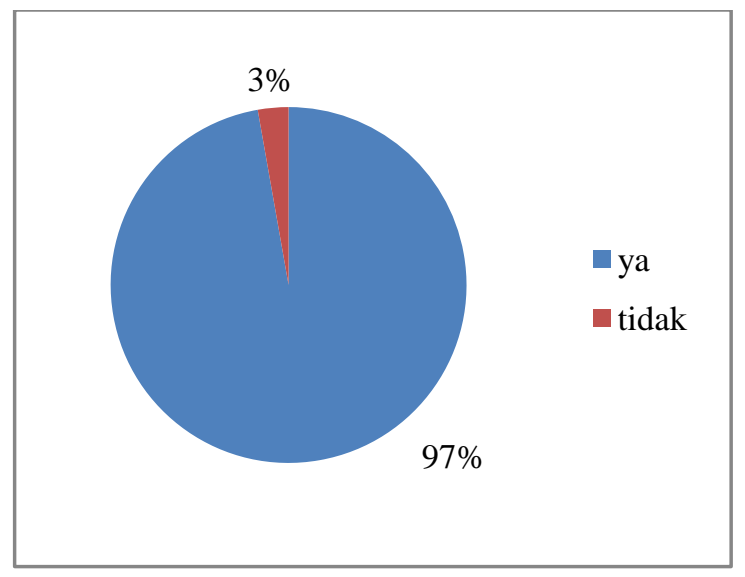

Gambar 6. Pendapat responden terhadap kualitas air untuk parameter rasa

Dapat dilihat pada Gambar 6 bahwa untuk responden yang menjawab "YA" sebanyak 70 responden atau sebesar $97 \%$ dikarenakan mayoritas responden telah mengetahui bahwa air yang mereka pergunakan setiap harinya memang tidak memiliki rasa, sedangkan untuk jawaban "TIDAK" yakni sebanyak 2 responden atau sebanyak $3 \%$ hal tersebut bisa saja terjadi bisa saja dikarenakan perilaku santri yang menggunakan wadah air yang kurang bersih.

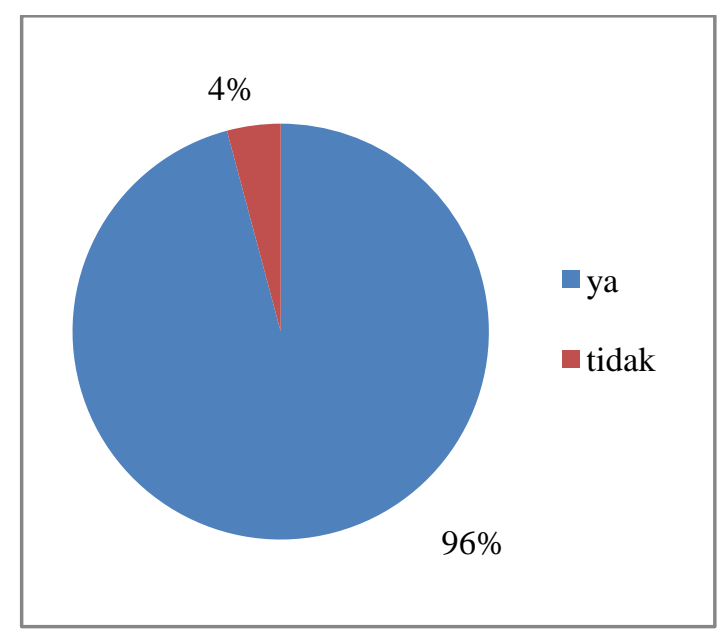

Gambar 7. Pendapat santri terhadap kualitas air parameter bau

Dapat dilihat pada Gambar 7 bahwa untuk responden yang menjawab "YA" sebanyak 69 responden atau sebesar 96\% dikarenakan mayoritas responden telah mengetahui bahwa air yang mereka pergunakan setiap harinya memang tidak memiliki berbau, sedangkan untuk jawaban "TIDAK" yakni sebanyak 2 responden atau sebanyak $4 \%$ hal tersebut bisa saja terjadi bisa saja dikarenakan perilaku santri yang menggunakan wadah air yang kurang bersih.

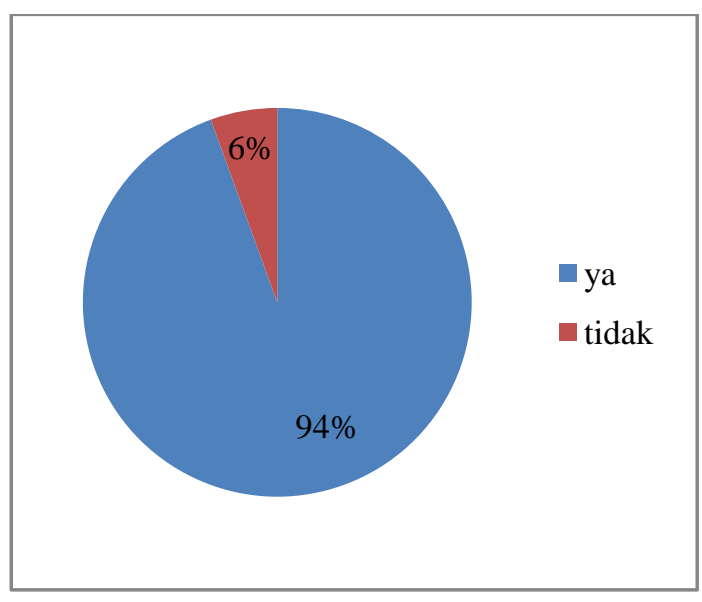

Gambar 8. Pendapat santri mengenai kualitas air parameter warna

Gambar 8 memperlihatkan bahwa untuk responden yang menjawab "YA" sebanyak 68 responden atau sebesar $94 \%$ dikarenakan mayoritas responden telah mengetahui bahwa air yang mereka pergunakan setiap harinya memang tidak memiliki warna, sedangkan untuk jawaban "TIDAK" yakni sebanyak 4 responden atau sebanyak $6 \%$ hal tersebut bisa saja terjadi bisa saja dikarenakan perilaku santri yang menggunakan wadah air yang kurang bersih.

\section{Persepsi tentang Air Limbah}

Beberapa kategori yang digunakan dalam kuesioner untuk akses air limbah, yaitu: sumber dan ketersediaan jamban, pemeliharaan sarana , akses pembuangan air limbah, serta penerapan perilaku hidup sehat. 


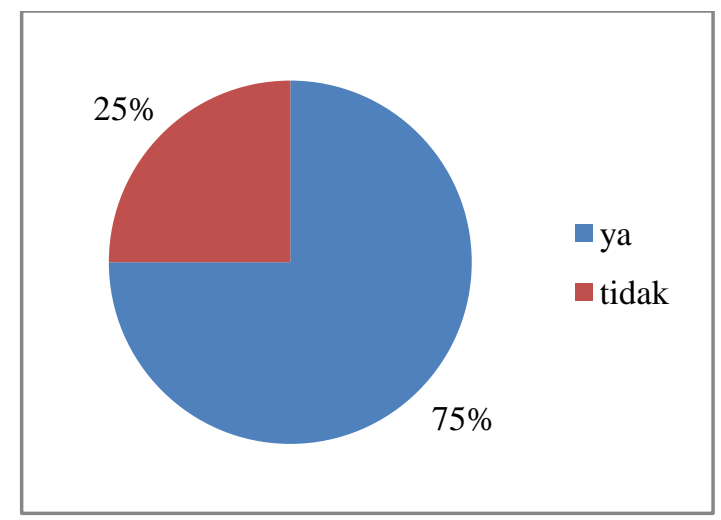

Gambar 9. Kondisi jamban/toilet yang terpisah dengan tempat wudhu/mandi/cuci

Dapat dilihat pada Gambar 9 diatas untuk responden yang menjawab "YA" sebanyak 54 responden atau sebesar $75 \%$ dikarenakan pondok pesantren memiliki jamban/toilet yang terpisah dengan tempat berwudhu dan mencuci, dan yang mennjawab "TIDAK sebanyak 18 responden atau sekitar $25 \%$ dikarenakan di salah satu pondok santri masih ada kran kran yang menyatu untuk berwudhu dengan mandi dan mencuci.

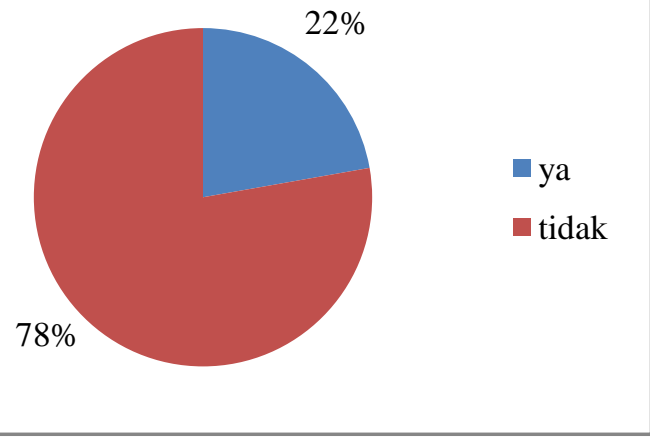

Gambar 10. Pendapat responden terhadap kecukupan jumlah toilet

Gambar 10 memperlihatkan bahwa untuk responden yang menjawab "YA" sebanyak 16 responden atau sebesar $22 \%$ dikarenakan toilet di beberapa ruangan tidak ada antrian, sedangkan yang menjawab "TIDAK" sebanyak 56 responden atau sekitar $78 \%$ dikarenakan toilet/ jamban seringkali terjadi antrian di beberapa ruangan pondok yang disetiap ruangan nya terdapat santri yang lebih banyak dari pada ruangan santri lainnya.

\section{Persepsi tentang Drainase}

Gambar 11 memperlihatkan bahwa untuk responden yang menjawab "YA" sebanyak 55 responden atau sebesar $76 \%$ karena drainase di pondok pesantren cenderung tidak mengalami sumbatan jika pemeliharaan dilakukan dengan baik, serta responden yang menjawab "TIDAK" sebanyak 17 responden atau sebesar $24 \%$ karena jika terjadi sumbatan di saluran air menjadi menggenang.

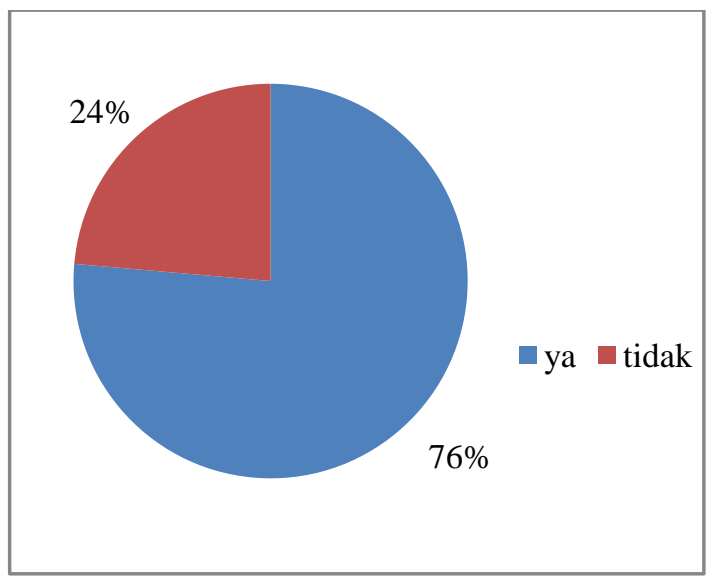

Gambar 11. Persepsi responden terhadap penyumbatan pada saluran drainase

Gambar 12 memperlihatkan bahwa untuk responden yang menjawab "YA" sebanyak 50 responden atau sebesar $69 \%$ karena drainase di pondok pesantren cenderung tidak mengalami sumbatan jika pemeliharaan dilakukan dengan baik, serta responden yang menjawab "TIDAK" sebanyak 22 responden atau sebesar 31\% karena ada beberapa bagian saluran yang harus diperbaiki. 


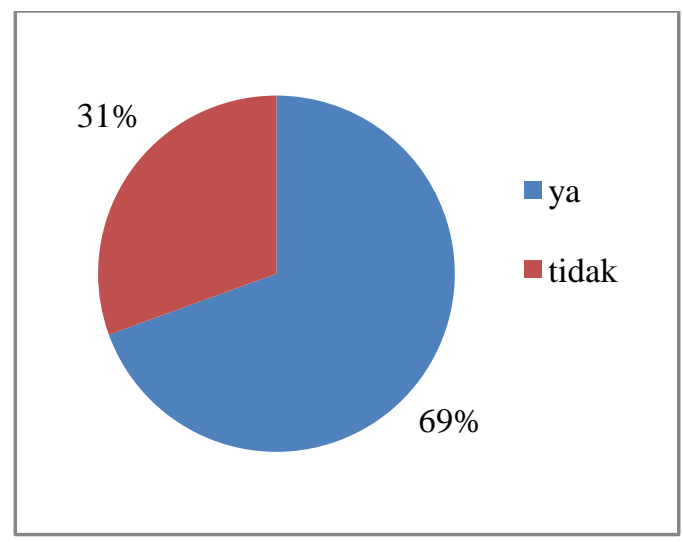

Gambar 12. Pendapat responden terhadap kelayakan dan pemeliharaan saluran drainase

\section{Persepsi tentang Persampahan}

Gambar 14 memperlihatkan bahwa untuk responden yang menjawab "YA" sebanyak 42 responden atau sebesar 58\% dikarenakan pondok pesantren melakukan kadang kala melakukan kegiatan pemilahan kadang kala sampah yang terkumpul langsung terbuang.

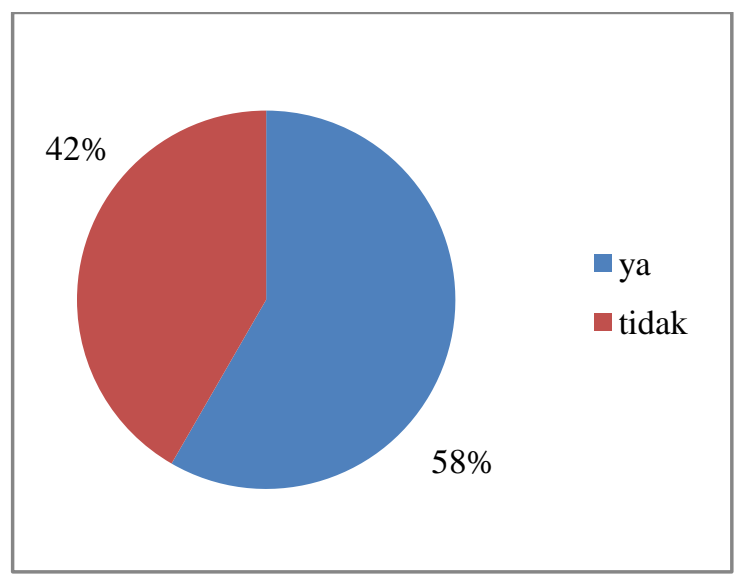

Gambar 12 Pendapat responden terhadap kegiatan pemilahan sampah

Gambar 13 memperlihatkan bahwa untuk responden yang menjawab "YA" sebanyak 31 responden atau sebesar $61 \%$, akan tetapi yang menjawab "TIDAK" sebanyak 41 responden atau 39\% pengelola tidak membuang sampah ke Tempat Pembuangan Akhir (TPA) melainkan dilakukan pembakaran dan organik dimasukkan kedalam biogas.

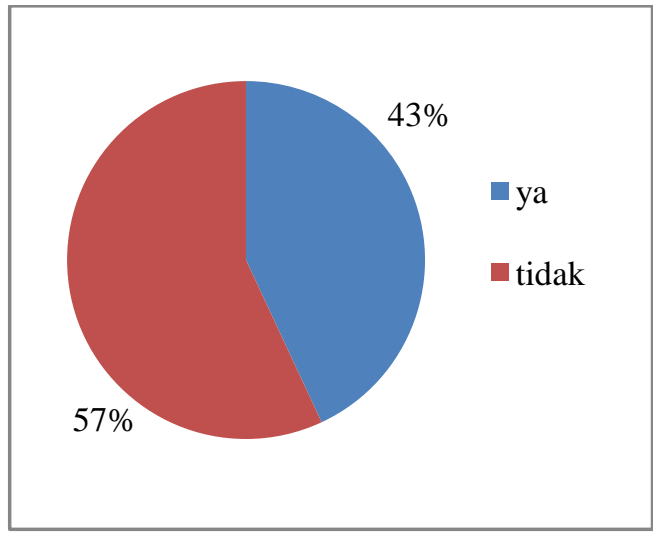

Gambar 13. Pendapat responden terhadap kegiatan pembakaran sampah

\section{Perencanaan Fasilitas Sanitasi}

a. Persampahan

Gambar 14 merupakan data timbulan sampah yang dihitung selama 8 hari pengamatan.

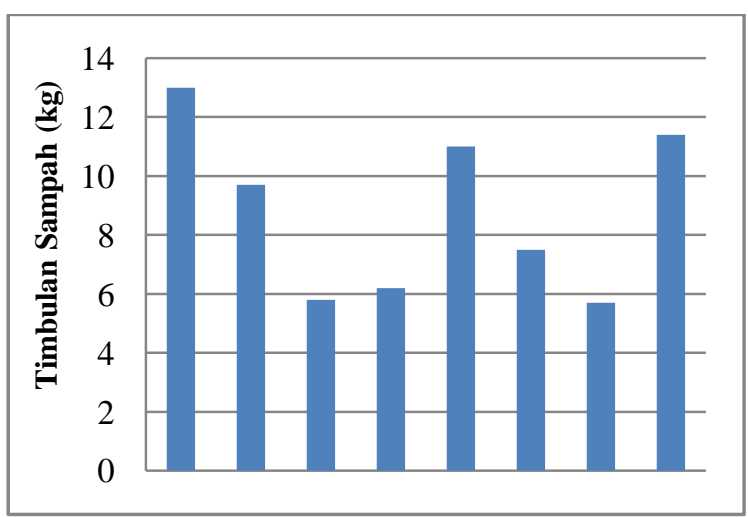

Gambar 14. Data Timbulan Sampah selama 8 hari

Dari kegiatan pengambilan sampling sampah yang dilakukan selama 8 hari berturut turut, sampah yang paling mendominasi yakni organik, plastik, kertas. Maka dari itu perlu dilakukan serangkaian kegiatan guna mengurani timbulan sampah yang dihasilkan contohnya dengan memilah secara benar sampah, melakukan pengomposan, mengoprasikan alat biogass secara maksimal yang nantinya gass yang dihasilkan dapat membantu untuk proses masak memasak dipondok pesantren, lalu 
penggunaan kembali barang-barang yang masih bisa dipergunakan, lalu menjual sampah yang memiliki nilai benefit tersendiri, membuat sampah menjadi suatu kerajinan dengan membangkitkan kreatifitas dan jiwa peduli terhadap lingkungan, pemberiansosialisasi pemahaman akan bahaya yang ditimbulkan akibat penumpukan atau pengelolaan sampah yang kurang baik.

Untuk kriteria pengomposan ialah sebagai berikut :

- Dimensi Tong Komposter

Diameter tong $=45 \mathrm{~cm}$

Tinggi tong $=90 \mathrm{~cm}$

- Timbulan sampah organik yang dapat dikomposkan yang dihasilkan oleh Pondok Pesantren Assalam adalah $40,1 \mathrm{Kg}$ atau sebesar $0,04 \mathrm{~m}^{3} /$ orang/hari

- Kapasitas satu buah tong komposter $=1 / 4 \times 3,14 \times(0,45 \mathrm{~m})^{2} \times 0,90 \mathrm{~m}$ $=0,14 \mathrm{~m}^{3}$

- Volume sampah organik yang dapat dikomposkan

$=0,04 \mathrm{~m} 3 /$ orang/hari $\times 260$ orang

$=10,4 \mathrm{~m}^{3} /$ hari

Jika diasumsikan waktu detensi selama 30 hari

Volume total $=10,4 \mathrm{~m}^{3} /$ hari $\times 30$ hari $=312 \mathrm{~m}^{3}$

Menghitung Kebutuhan Tong

$$
\begin{aligned}
& =\frac{\text { Volume total }}{\text { Kapasitas } 1 \text { tong }} \\
& =\frac{\mathbf{3 1 2} \mathbf{~ m}^{\mathbf{3}}}{\mathbf{0 , 1 4} \mathbf{~ m}^{\mathbf{3}}} \\
& =2228,5 \text { atau } 2229 \text { buah . }
\end{aligned}
$$

\section{b. Air bersih}

Kebutuhan air dapat dihitung sebagai berikut :

- Sumber air di Pondok Pesantren Yakni menggunakan air tanah dan memili 3 sumur bor.
- Debit pompa $\mathrm{Q}=30 \mathrm{~L} / \mathrm{menit}$

- Waktu operasional : pagi 2 jam, siang 2 jam, malam 2jam.

- $\quad \mathrm{Q} \times \mathrm{td}=30 \mathrm{~L} / \mathrm{menit} \times 60$ menit $=1800$

$\mathrm{L} /$ menit $=10800 \mathrm{~L}=32,4 \mathrm{~m}^{3} /$ hari

- Kebutuhan air $=260$ orang x $105 \mathrm{~L} / \mathrm{o} / \mathrm{h}$ $=27300 \mathrm{~L} / \mathrm{h}=27,3 \mathrm{~m} / \mathrm{hari}$

- Analisis : suply : $32,4 \mathrm{~m}^{3} / \mathrm{hari}=32,4$ $\mathrm{m}^{3} /$ hari $-27,3 \mathrm{~m}^{3} /$ hari $=5,1 \mathrm{~m}^{3} /$ hari

\section{c. Air Limbah}

Perencanaan penanganan air limbah di Pondok Pesantren Assalam yaitu dengan menggunakan tangki septik. Asumsi seluruh buangan masuk ke dalam tangki septik (Miswary \& Indarjanto, 2017).

$\mathrm{S}=40 \mathrm{~L} / \mathrm{o} / \mathrm{h}:$ untuk sumber wc, dapur, dll

Faktor air buangan $(\mathrm{fab})=80 \%=0,8$

Menghitung minimum kapasitas :

$$
\begin{aligned}
& \text { A = Qam } \times \text { fab } \\
& 31200 \text { Lh x 0,8=24960 1/h }
\end{aligned}
$$

- Volume penampungan lumpur dan scum

$$
\mathrm{B}=\mathrm{P} \times \mathrm{N} \times \mathrm{F} \times \mathrm{S}
$$$$
=85 \times 5 \times 1 \times 40 \mathrm{l} / \mathrm{o} / \mathrm{h}
$$$$
=17.000 \mathrm{l} / \mathrm{h}
$$

- Menghitung total volume tangki septik

$$
\begin{aligned}
C & =A+B \\
C & =249601 / h+17.0001 / h \\
& =419601 / h=41,96 m^{3} / h
\end{aligned}
$$

Tinggi tangki septik $1.5 \mathrm{~m}$

$$
\begin{aligned}
& \mathrm{Vol}=\mathrm{p} \times 1 \times \mathrm{t} \\
& =4,5 \mathrm{I}^{2}=41,96 \mathrm{~m}^{3} / \mathrm{h} \\
& \mathrm{I}=\sqrt{ } 41,96 \mathrm{~m}^{3}: 4,5=3,1 \mathrm{~m}
\end{aligned}
$$

Kebutuhan fasilitas sanitasi

- $\quad$ Kamar mandi $=260$ santri : $10=26$ unit- 18 unit $=8$ unit

- Cuci $=100$ unit $: 8$ santri $=13$ santri (1 unit) 
Menghitung kebutuhan= 260 santri : 13 santri $=$ 20 unit.

Kakus $=100$ unit $: 16$ santri $=7$ santri

Menghitung kebutuhan $=260$ santri $: 7$ santri $=$ 37 unit -18 unit $=19$ unit yang direncanakan

Karena kakus disatukan dengan kamar mandi maka pembangunan kamar mandi dengan ruang kakus sebanyak 8 unit.

- Jumlah kamar mandi yang direncanakan $=8$ unit

- Kontruksi pembuatan ruang mandi dan kakus $=3$ ruang mandi dan kakus/ tahun.

- $\quad$ Lama Kontruksi $=\quad \underline{8 \text { ruang mandi }}$ dan kakus $\quad=2,7$ tahun (3 ruang mandi dan kakus/ tahun)

Sehingga untuk memenuhi kebutuhan ruang mandi dan kakus di Pondok Pesantren Assalam diperlukan waktu 2,7 tahun jika dibangun 3 ruang mandi dan kakus setiap tahunnya.

Tabel 3. Perencanaan MCK

\begin{tabular}{lccc}
\hline \multirow{2}{*}{$\begin{array}{c}\text { Jenis } \\
\text { Sarana/Dimensi }\end{array}$} & $\begin{array}{c}\text { Lay } \\
\text { Santri }\end{array}$ & $\begin{array}{c}\mathbf{1 0 0 0} \\
\text { Santri }\end{array}$ & $\begin{array}{c}\mathbf{3 0 0 0} \\
\text { Santri }\end{array}$ \\
& (Unit) & (Unit) & (Unit) \\
\hline Mandi (1,7 x 1,10) m & 10 & 100 & 300 \\
Cuci $(1,00 \times 0,9)$ & 8 & 80 & 240 \\
Kakus $(1,40 \times 0,80)$ & 16 & 160 & 480 \\
Peturasan & 9 & 90 & 270 \\
Kran/Pancuran & 4 & 40 & 120 \\
& & & \\
\hline
\end{tabular}

Sumber: Petunjuk Teknis Pt-T-18-2002-C

\section{Kesimpulan}

Setelah melakukan perhitungan pada air bersih, air buangan dan dimensi tangki septik, drainase dan persampahan, maka diperoleh kesimpulan sebagai berikut :

1. Untuk sarana penyediaan air bersih dan air limbah, jumlah toilet eksisting adalah sebanyak 18 unit, dengan kondisi harus dalam perbaikan. Sedangkan menurut perhitungan jumlah toilet maka sebaiknya terdapat 26 unit toilet. Dengan jumlah penambahan pada toilet santri pria sebanyak 2 buah dan toilet santri putri 6 buah.

2. Pada persampahan pengoptimalan alat biogass yang sudah ada, pemilahan lebih teliti terhadap sampah yang dihasilkan, penggunaan kembali benda yang dapat dipergunakan guna mengurangi timbulan sampah, pengomposan dengan penggunaan komposter.

3. Pada akses drainase Intensitas Curah hujan $50 \mathrm{~mm} /$ hari, Laju peresapan air 3liter/ menit $=4320$ liter/ hari , Luas bidang $=2005 \mathrm{~m}^{2}$ maka dapat dibuat 22 lubang biopori.

4. Rencana anggaran biaya yang dibutuhkan untuk membangun 8 unit toilet yaitu sebesar Rp 10.636.602 dan biaya untuk membangun tangki septik up-flow 10.022.424, untuk biopori Rp 5.235.000, dan perbaikan Tempat Pembuangan Sementara sebesar $\mathrm{Rp}$ 427.477 dengan dimensi $2 \mathrm{~m} \mathrm{x} 2 \mathrm{~m} \mathrm{x}$ $1,5 \mathrm{~m}$.

\section{Daftar Pustaka}

Miswary, T., \& Indarjanto, H. W. (2017). Evaluasi Sistem Plambing, Instalasi Pengolahan Air Limbah dan Pengelolaan Sampah di Rumah Susun Gunung Sari Kota Surabaya. Jurnal Teknik ITS, Vol. 6, No. 2: D104-D110.

Parman, Hamdani, Rachman, I., \& Pratama, A. (2017). Faktor Risiko Hygiene Perorangan Santri terhadap Kejadian Penyakit Kulit Skabies 
di Pesantren Al-Baqiyatushshalihat Tanjung Wahyudin, U., \& Arifin, H. S. (2015). Jabung Barat Tahun 2017. Jurnal Ilmiah Sosialisasi Sanitasi Diri dan Lingkungan di Universitas Batanghari Jambi, Vol 17, No 3: Pesantren Salafi melalui Pos Kesehatan 243-252.

Sevilla, \& al, e. (2007). Research Methods. Quezon City: Rex Printing Company. Pesantren (Poskestren) dalam Membentuk Sikap Santri terhadap Sanitasi. Jurnal Kajian Komunikasi, Vol 3, No 2: 148-153. 